\title{
Filcavost listavcev (Septobasidium marianii Bres.): spregledana bolezen sadnega drevja v Sloveniji
}

\author{
Barbara PIŠKUR ${ }^{1,2}$ in Dušan JURC ${ }^{1,3}$
}

\author{
Received May 09, 2019; accepted June 12, 2019. \\ Delo je prispelo 09. maja 2019, sprejeto 12. junija 2019.
}

Filcavost listavcev (Septobasidium marianii Bres.): spregledana bolezen sadnega drevja v Sloveniji

Izvleček: $\mathrm{V}$ prispevku poročamo o najdbi bolezni hrušk (Pyrus communis 'Konferans', 'Abate Fetel') in našija (Pyrus pyrifolia (Hosui') v dolini reke Soče, na skrajnem zahodnem delu Slovenije (E:13.58844 $\left.{ }^{\circ}, \mathrm{N}: 46.04117^{\circ}\right)$. Na zdravih in odmirajočih vejah gostiteljskih dreves smo $\mathrm{z}$ molekularnimi in morfološkimi metodami identificirali glivo Septobasidium marianii Bres. ter ugotovili, da trosnjaki glive vsebujejo kolonije rdečega hruševega kaparja (Epidiaspis leperii (Signoret 1869)). Opisane so značilnosti mutualistične simbioze, ki jo oblikujeta gliva in kaparji ter značilnosti bolezni filcavost listavcev, ki prizadene gostiteljske rastline. Navedeni so ukrepi za kontrolo bolezni, ki jih priporočajo v literaturnih virih. Prispevek predstavlja prvo poročilo o pojavu bolezni filcavosti listavcev v Sloveniji.

Ključne besede: bolezen; filcavost listavcev; hruška; naši; Septobasidium marianii; Epidiaspis leperii; Slovenija
Felt disease (Septobasidium marianii Bres.): an overlooked disease of fruit trees in Slovenia

Abstract: We report the finding of the disease of pear (Pyrus communis 'Konferans', 'Abate Fetel') and nashi trees (Pyrus pyrifolia 'Hosui') in the Soča river valley in the westernmost part of Slovenia $\left(\mathrm{E}: 13.58844^{\circ}, \mathrm{N}: 46.04117^{\circ}\right)$. On healthy and moribund branches of host trees, the fungus Septobasidium marianii Bres. was identified with morphological and molecular methods. In the basidiomes colonies of European pear scale (Epidiaspis leperii (Signoret 1869)) were observed. Mutualistic symbiosis formed by the fungus and the scale insects is explained and the characteristics of felt disease affecting host plants is described. Listed are the disease control measures recommended in the literature. The article is the first report of the occurrence of felt disease in Slovenia.

Key words: disease; felt disease; pear; nashi; Septobasidium marianii; Epidiaspis leperii; Slovenia

1 Gozdarski inštitut Slovenije, Oddelek za varstvo gozdov, Ljubljana, Slovenija

2 Korespondenčni avtor, e-naslov: barbara.piskur@gozdis.si

3 Inštitut za drevo, Ljubljana, Slovenija (sedanji naslov) 


\section{UVOD}

Bolezni rastlin niso vedno posledica škodljivega delovanja patogenov, ki ga lahko dokažemo s Kochovimi postulati. Glive iz družine Septobasidiaceae imajo poseben način življenja in prehranjevanja, pogosto pa je njihov pojav povezan $s$ hiranjem in odmiranjem lesnatih rastlin. Vendar glive iz te skupine ne parazitirajo rastlin na katerih rastejo, temveč parazitirajo na teh rastlinah namnožene kaparje (Coccoidea). Trofični odnos med glivo in kaparji ni tipičen parazitski, označujejo ga celo kot mutualistično simbiozo (Couch, 1931; Couch, 1938). Gliva, ki zajeda kaparje, jim namreč nudi tudi številne koristi. Njeni trosnjaki prekrivajo kolonije kaparjev in jih ščitijo pred predatorji, parazitoidi in neugodnimi ekološkimi dejavniki. Gliva parazitira le posamične osebke $\mathrm{v}$ koloniji kaparjev in ti ne odmrejo, ampak so celo bolj dolgoživi kot neokuženi, izgubijo le sposobnost razmnoževanja in so manjši kot neokuženi (Henk, 2008). Številčnejši neparazitirani kaparji pa imajo $\mathrm{v}$ trosnjakih ugodnejše razmere za preživetje $\mathrm{v}$ primerjavi $\mathrm{z}$ osebki zunaj trosnjakov. Rastlina, tretji partner v tej simbiozi, lahko hira in včasih celo odmre zaradi namnožitve in škodljivega delovanja kaparjev. Glive iz družine Septobasidiaceae so torej udeležene pri povzročanju bolezni $\mathrm{z}$ zaščito in ustvarjanjem razmer za namnožitev kaparjev. Ni nam znano, ali je bil doslej v Sloveniji ugotovljen opisani tip bolezni in v osrednji podatkovni zbirki gliv v Sloveniji Boletus informaticus ni zabeležene nobene glive iz družine Septobasidiaceae (https://www.zdravgozd.si/bi_index.aspx). Po značilnem izgledu trosnjakov, ki prekrivajo skorjo gostiteljskega drevesa kot polstena, klobučevinasta prevleka, predlagamo za ime bolezni izraz »filcavost listavcev« (angl. felt disease). O pojavu hiranja hrušk, našija in jablan nas je obvestil lastnik sadovnjaka iz Plav pri Desklah.

\section{MATERIAL IN METODE}

\subsection{MORFOLOŠKA IDENTIFIKACIJA}

Vzorci hruševih vejic (Pyrus communis 'Konferans', 'Abate Fetel') in našija (Pyrus pyrifolia 'Hosui') s trosnjaki gob so bili nabrani 5. 2. 2019 in 14. 3. $2019 \mathrm{v}$ Plavah (E:13.58844 $\left.{ }^{\circ}, \mathrm{N}: 46.04117^{\circ}\right)$. Vzorce smo navlažili in jih dva do štiri dni gojili na vlažnem filtrirnem papirju $\mathrm{v}$ petrijevki pri sobni temperaturi. Trose za mikroskopski pregled smo pridobili tako, da smo pod navlažene trosnjake v petrijevki za dva dni namestili objektno stekelce za mikroskopiranje in zbrali trosni depozit. Vzorce smo pregledali z binokularjem Olympus SZX 16, opremlje- nim s kamero Olympus UC90 ter z mikroskopom Olympus BX53, opremljenim s kamero Olympus DP26. Fotografirali smo s programom cellSens Standard in z njim tudi opravili vse meritve. Trosi so bili izmerjeni z 20 meritvami, mere smo zaokrožili na $0,5 \mu \mathrm{m}$. Reprezentativni vzorec smo shranili v Mikoteki Gozdarskega inštituta Slovenije (LJF) s številko 7006.

\subsection{MOLEKULARNA IDENTIFIKACIJA}

Iz sveže nabranega vzorca (hruševe vejice s trosnjaki) smo s sterilnim skalpelom odstranili tanek vrhnji del trosnjaka, nato pa izrezali približno $0,25 \mathrm{~cm}^{2}$ velik košček, ki smo ga uporabili za molekularno identifikacijo. Genomsko DNA smo ekstrahirali s komercialnim kitom Nucleospin Plant II (Macherey-Nagel), vzorec pa smo pred postopkom homogenizirali z uporabo tubic Lysing Matrix A (MB Biomedicals), ki smo jih stresali na homogenizatorju Precellys Evolution (Bertin Technologies). Reakcijo PCR z univerzalnimi začetnimi oligonukleotidi ITS1 in ITS4 (White et al., 1999) smo izvedli po postopku opisanem v Hauptman in Piškur (2016). Produkte PCR smo očistili $s$ kompletom za čiščenje produktov PCR (Promega). Obe verigi produkta PCR smo sekvencirali $\mathrm{v}$ ločenih reakcijah z začetnima oligonukleotidoma, ki smo ju uporabili tudi za PCR. Sekvenciranje je izvedlo podjetje Eurofins Genomics. Nukleotidna zaporedja smo pregledali s programom GeneiousPrime. Dobljeno nukleotidno zaporedje smo primerjali z zaporedji iz zbirke GenBank z algoritmom BLASTn (izvedba na dan 18. 4. 2019). Iz zbirke GenBank smo pridobili tudi zaporedja, ki smo jih vključili v filogenetsko analizo, predvsem zaporedja iz raziskave, ki sta jo opravila Henk in Vilgalys (2007). S spletno različico programa MAFFT z algoritmom E-INS-i (Katoh et al., 2005) smo pridobljena zaporedja poravnali ter $\mathrm{z}$ metodo največjega verjetja ("maximum likelihood", ML) s programom RAxML (Stamatakis, 2006; Stamatakis et al., 2008) izračunali ML-filogenetska drevesa, statistične podpore posameznih cepitev $\mathrm{v}$ drevesih pa smo izračunali $\mathrm{z}$ neparametričnim testom samovzorčenja (»bootstrap«) s 1000 ponovitvami.

\section{REZULTATI IN RAZPRAVA}

Nukleotidno zaporedje regije ITS rDNA v dolžini $541 \mathrm{bp}$, ki smo ga pridobili tekom identifikacije neznane glive na vzorcu hruševih vej, smo s primerjavo javno dostopnih nukleotidnih zaporedij v zbirki GenBank ter po filogenetski primerjavi dostopnih zaporedij (slika 1) določili kot vrsto iz rodu Septobasidium. Med dostopnimi zaporedji v GenBank je slovenskemu vzorcu najbolj so- 


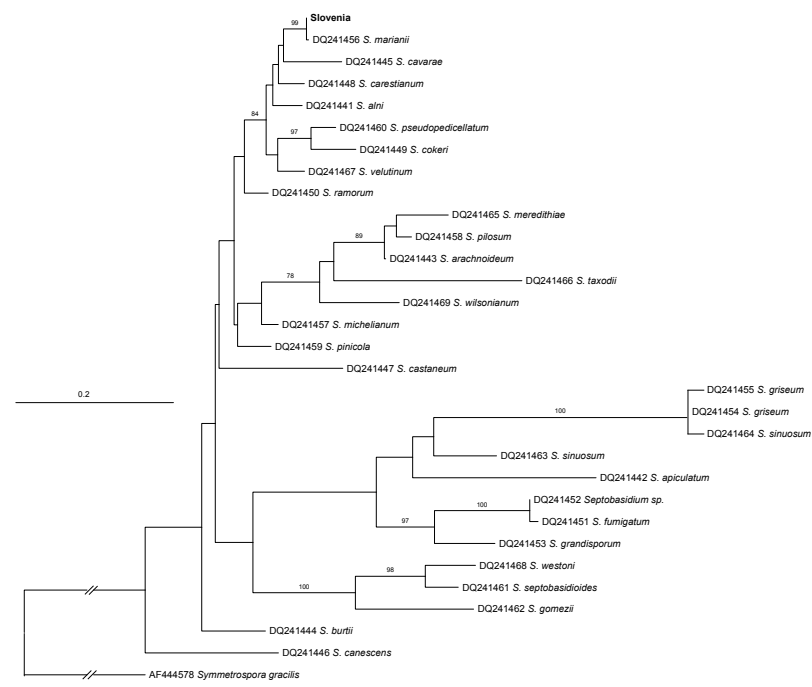

Slika 1: Filogenetsko drevo izbranih vrst gliv iz rodu Septobasidium, pridobljenih iz zbirke GenBank, narejeno po analizi nukleotidnih zaporedij ITS rDNA. Merilo predstavlja število nukleotidnih zamenjav. Krepko je označen vzorec iz Slovenije. Imena vrst sledijo vrstnemu poimenovanju v zbirki GenBank.

Figure 1: Phylogenetic tree of selected species from Septobasidium genus based on the ITS-rDNA data set, with sequences obtained from GenBank. Scale bar indicates nucleotide substitutions per site. Sample from Slovenia is marked in bold. Species names are the same as in the GenBank.

rodna vrsta Septobasidium marianii Bres.. Nukleotidno zaporedje smo shranili v zbirko GenBank (MK809161).

Molekularna identifikacija je bila potrjena $\mathrm{z}$ morfološko identifikacijo. Na vzorcih smo identificirali glivo Septobasidium marianii in rdečega hruševega kaparja (Epidiaspis leperii (Signoret 1869)). Trosnjaki glive S. marianii so bili opaženi tudi v več sadovnjakih nedaleč stran od mesta nabiranja vzorcev, poleg hrušk in našijev
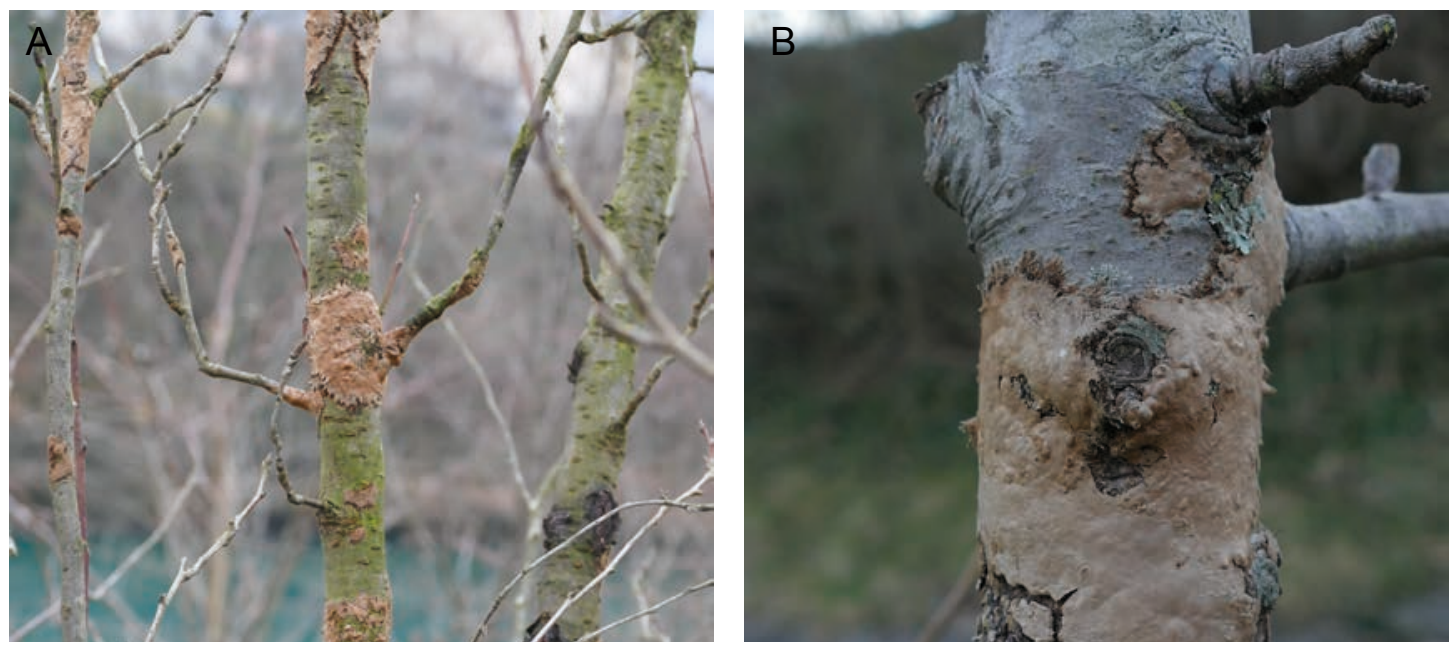

Slika 2: Trosnjaki Septobasidium marianii prekrivajo debelca in veje hruške (A) (foto S. Križnič), star trosnjak z odmirajočim centralnim delom pozimi (B) (foto S. Križnič, februar 2019)

Figure 2: Basidiomes of Septobasidium marianii cover pear's trunk and branches (A), an old basidiome with moribund central part in winter (B) (photo S. Križnič, February 2019) 

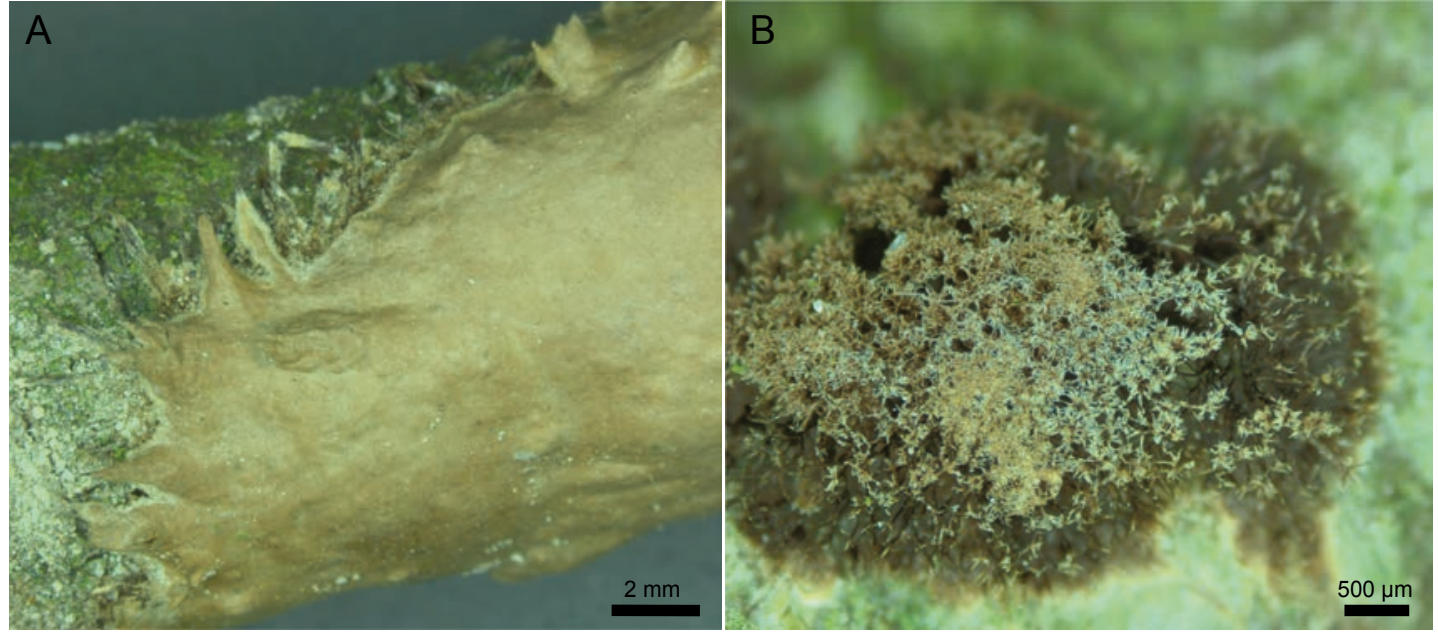

Slika 3: Osušen trosnjak je cimetasto rjav, prirastna cona trosnjaka ni oblikovana zaradi časa nabiranja (pozimi, 5. 2. 2019) (A), spužvast osrednji del trosnjaka pričenja oblikovati zgornjo plast - trosovnico (B)

Figure 3: Dried fruitbody is cinnamon brown, growing zone is not formed due to collection time (winter) (A), spongy central part of fruitbody begins to form upper part - hymenium (B)

okrogli ali ovalni in do $10 \mathrm{~cm}$ ali več v premeru, včasih so zraščeni med sabo (slika 2A, 2B).

So membranasti, debeli 1-2 mm, gladki in se prilegajo skorji drevesa, na kateri se oblikujejo, lahko se ovijajo okoli cele veje ali debelca. Na starih trosnjakih so v obdobju vegetacije opazne tri koncentrične cone: osrednji del, kjer trosnjak odmira in razpada, sledi gladek predel z zrelo trosovnico, ki oblikuje trose, ter robni del, kjer trosnjak $\mathrm{v}$ rastnem obdobju prirašča in trosovnica še ni oblikovana (slika 2B). Barva svežih trosnjakov je najprej oker, nato rjava, rdeče rjava, lahko celo krvavo rdeča ali vijolična. Osušeni trosnjaki so vedno značilno cimetno rjave barve (slika $3 \mathrm{~A}$ ). V prečnem prerezu trosnjaka so opazne tri plasti, dobro razločne z ročno lupo $(10 \times)$ : spodnja plast (subiculum) je 0,1-0,3 mm debela, sestavljena iz kompaktnih črnih hifnih povezkov, blazinic ali stebričkov, ki omejujejo kamrice in predore, $\mathrm{v}$ katerih so ujeti kaparji. Vsaka kamrica s kaparjem ima izrazito tanko membranasto streho. Tej plasti sledi rahel spužvast srednji del (context) ki je sestavljen iz 0,5-0,8 mm visokih

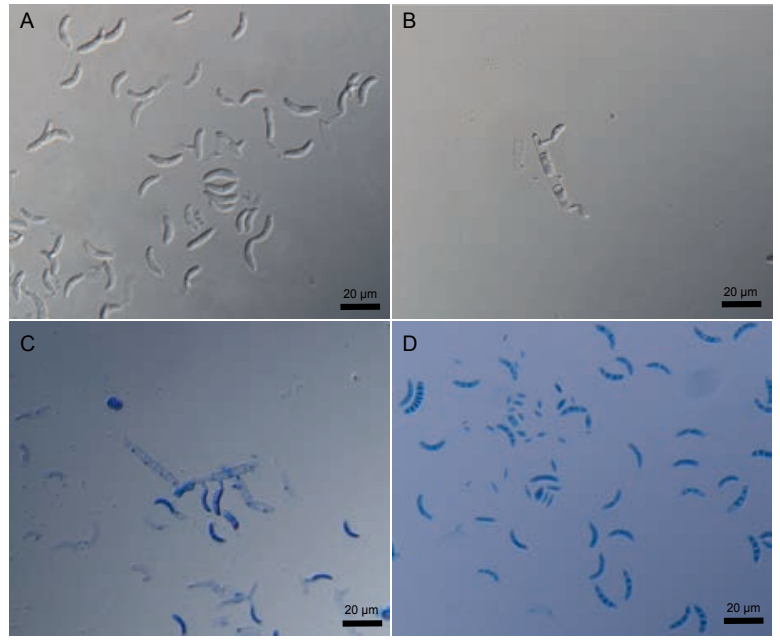

Slika 4: Bazidiospore glive S. marianii, nekatere brstijo (v vodi) (A), bazidij z dvema bazidiosporama (v vodi) (B), bazidiji in bazidiospore obarvane $\mathrm{z}$ laktofenol metilenskim modrilom $(\mathrm{C})$, trosni prah po dveh dneh, septiranost bazidiospor se povečuje, manjši trosi so brstiči, pukciniomicetne kvasovke (D)

Figure 4: Basidiospores of S. marianii, some are budding (in water) (A), basidium with two basodiospores (in water) (B), basidium and basidiospores of $S$. marianii stained with lactophenol cotton blue (C), spore print after two days, septation is increasing, smaller spores are pucciniomycetous yeasts (D) 
in 20-80 $\mu \mathrm{m}$ širokih stebričkov temno rjavih do črnih hifnih povezkov, ki so zgoraj in spodaj močno razvejani, med sabo pa se tudi zraščajo in prepletajo (slika 3B).

Hife imajo izrazito debelo, temno obarvano steno. Zgornja plast trosnjaka je trosovnica (himenij), ki je 30-80 $\mu \mathrm{m}$ debela. V njej se prepletajo tankostenske hife, ki oblikujejo probazidije. Ti merijo $20-25 \times 9-12 \mu \mathrm{m}$ in iz njih poženejo bazidiji. Bazidiji so prečno predeljeni s tremi pregradami (septami) in imajo štiri sterigme, ki so 4-6 $\mu \mathrm{m}$ dolge (slika 4B, 4C). Bazidiji so valjasti s tanko prosojno (hialino) steno, hitro odpadejo od probazidija, dolgi so $35,0(31,0-37,0) \mu \mathrm{m}$ in široki $4,5(3,5-5,0) \mu \mathrm{m}$ (slika 4B, 4C). Bazidiospore so podolgovate in ukrivljene, brez oziroma $\mathrm{z}$ do tremi pregradami (septami) (slika 4A, 4D), v navlaženem trosnem depozitu se v bazidiosporah oblikujejo še dodatne pregrade in posamična bazidiospora jih vsebuje do sedem (slika $4 \mathrm{D}$ ). Bazidiospore merijo $15,5(11,5-18,0) \times 3,5(3,0-4,5) \mu \mathrm{m}$. Bazidiospore brstijo v številne posamične celice, ki jih označujejo $\mathrm{z}$ izrazom bazidiomicetne kvasovke. Te so zelo različne velikosti in $\mathrm{v}$ pregledanih vzorcih so merile $7,0(5,0-9,0) \times 2,5(2,0-4,0)$ $\mu \mathrm{m}$ (slika 4D).

Samice rdečega hruševega kaparja (E. leperii) smo našli v kamricah spodnje plasti trosnjaka (slika 5A) in številne primerke tudi na skorji gostiteljskih dreves $\mathrm{v}$ okolici trosnjakov (slika 5B).

Pri mikoloških determinacijah običajno ne identificirajo vrste simbiontskega kaparja, ki živi v trosnjakih in navajajo, da je gliva sposobna simbioze s številnimi vrstami (Azema, 1975). V Sloveniji je bil rdeči hrušev kapar ugotovljen na naslednjih gostiteljih: Aesculus hippocastanum L., Juglans regia L., Malus domestica, Ostrya carpinifolia Scop., Prunus domestica L. in Pyrus communis L.
(Seljak, 2010) in domnevamo, da bi zato lahko bila gliva razširjena tudi na drugih gostiteljskih rastlinah.

Azema (1975) navaja kot gostitelje glive S. marianii naslednje rastline: Quercus ilex L., Q. nigra L., Malus sylvestris (L.) Mill., M. angustifolia (Aiton) Michx., Pyrus communis, Crataegus spp., Ligustrum vulgare L., Cornus sanguinea L. in Phyllirea media L. Julich (1984) navaja poleg naštetih še ambrovec (Liquidambar) in Saccardo P.A. in Saccardo D. (1905) tudi Quercus robur L.. Zanimivo je poročilo iz Švice (Martini, 2016), kjer so navedene številne najdbe te glive, vendar so bile vse najdbe na navadni leski (Coryllus avellana L.) ali na nedoločenem gostitelju. V nam dostopni literaturi ne navajajo, da je bila gliva S. marianii najdena na našiju (Pyrus pyrifolia) in verjetno predstavlja ta prispevek prvo poročilo o najdbi na tem gostitelju.

Najdba glive S. marianii v dolini reke Soče ni presenetljiva, saj npr. Saccardo P.A. in Saccardo D. (1905) poročata o najdbah te vrste $\mathrm{v}$ vasi Montello blizu Trbiža (Treviso) v Italiji in v vasi Miane pri Trbižu. Lokacije pri Trbižu so oddaljene približno $100 \mathrm{~km}$ zračne razdalje od nahajališča v Plavah in ekološke razmere (predvsem toplo in vlažno poletje) so si na obeh območjih zelo podobne. Azema (1975) navaja, da gliva S. marianii ni redka in domnevamo, da je bila pri nas spregledana tako s strani mikologov, kot tudi s strani strokovnjakov za varstvo rastlin.

Red Septobasidiales delijo na dve družini in Septobasidiaceae obsegajo približno 180 vrst, večinoma v rodu Septobasidium, ki obsega približno175 vrst. To so slabo raziskane glivne skupine. Najpomembnejše značilnosti je razjasnil Couch (1931 in 1938), ki je podrobno opisal življenjski krog gliv iz rodu Septobasidium in njihovo


Slika 5: Rdeči hrušev kapar (Epidiaspis leperii) v kamrici spodnje plasti trosnjaka (A), rob trosnjaka začenja preraščati kaparje (B) Figure 5: European pear scale(Epidiaspis leperii) in an insect house in basal part of the fruitbody (A), edge of fruitbody is beginning to overgrow scale inescts (B) 
povezanost $s$ kaparji, kasneje pa se $\mathrm{z}$ njimi raziskovalno niso več ukvarjali (Oberwinkler, 2017). Kljub jasnim dokazom, da je sožitje glive iz rodu Septobasidium in kaparjev mutualistična simbioza, pa nekateri avtorji te glive vseeno prištevajo med tipične antagonistične entomopatogene glive za kaparje (Porcelli, 2013). Družina je v najbližjem sorodstvu z rjami (Pucciniales), saj ima prečno predeljen bazidij, probazidij pa je funkcionalno teliospora (zimski tros). Poleg teh morfoloških značilnosti so tudi molekularne analize in elektronska mikroskopija pokazale največjo sorodnost z rjami (Henk \& Vilgalys, 2007). Bazidiospore niso sposobne okužiti gostiteljskih kaparjev. Okužbo opravijo trosi (bazidiomicetne kvasovke), ki brstijo iz bazidiospor in so zato haploidni (Oberwinkler, 2017; Henk, 2008). Okužijo se posamezne ličinke, ki se izležejo v labirintu trosnjaka. Brstiči iz bazidiospor okužijo ličinke skozi naravne odprtine (spolna, zadnjična, žleze v povrhnjici, kljunec) in kalijo v havstorije (sesalne hife). Ti so značilno vijugasto zaviti in lahko pomenijo pri nekaterih vrstah pomemben taksonomski znak. Okužene ličinke kaparjev so gibljive in pogosto zapustijo trosnjak in se naselijo drugje. Tam se pritrdijo, pričnejo sesati gostiteljsko rastlino in iz njih zrastejo hife ter začnejo oblikovati trosnjak po tem, ko se dikariotizirajo s stikom s hifami drugega glivnega osebka (to se zgodi v trosnjaku, kjer se izležejo, ali kasneje, ko pridejo v stik z drugimi okuženimi ličinkami).

V Evropi poročajo o osmih vrstah iz rodu Septobasidium (Azema, 1975; Jülich, 1984), vendar številni avtorji poudarjajo, da je rod vrstno bogat predvsem $\mathrm{v}$ tropih. Nekatere vrste se pojavljajo le na posameznih rodovih ali vrstah drevja (npr. Septobasidium alni Torrend na jelšah, Septobasidium quercinum (De Not. \& Bagl.) Sacc. na hrastih, Septobasidium fuscoviolaceum Bres. na Salix cinerea L.), nekatere pa na več gostiteljskih rastlinah (npr. Septobasidium orbiculare (Durieu \& Lév.) Donk na navadnem lovorju (Laurus nobilis L.) in še na šestih gostiteljih. Med vsemi znanimi evropskimi vrstami iz rodu Septobasidium najdemo na največjem številu gostiteljskih rastlin vrsto S. marianii. Center speciacije rodu Septobasidium je domnevno Južna Amerika (Viennot-Bourgin, 1949). $\mathrm{V}$ zadnjih letih opisujejo precej novih vrst kitajski, korejski in japonski avtorji v toplejših območjih (npr. Choi et al., 2016), z genetskimi raziskavami gliv v kavčukovcu (Hevea) pa so celo ugotovili dve neopisani vrsti, ki sta endofitsko prisotni (Martin et al., 2015).

O značilni bolezni filcavosti in njeni škodljivosti poročajo predvsem iz ZDA, kjer se Septobasidium pseudo-pedicellatum Burt. pojavlja na vrstah iz rodov Fraxinus, Alnus, Pyrus in številnih hrastih. Močne poškodbe so povezane s pojavom glive Septobasidium castaneum na vrsti hrasta Quercus phellos L. in Q. nigra, na splošno pa glive iz rodu Septobasidium v ZDA veljajo za pomemb- ne dejavnike pri pojavu filcavosti in poškodbah hrušk, jablan, gozdnega drevja ter citrusov (Viennot-Bourgin, 1949). Splošna navodila za zatiranje teh gliv v starejših virih obsegajo fizično odstranjevanje vej s trosnjaki, odstranjevanje trosnjakov s krtačenjem ali strganjem ter škropljenje $\mathrm{z}$ bakrovimi fungicidi ali z žvepleno apneno brozgo (McRitchie, 1991; Viennot-Bourgin, 1949). V novejših objavah priporočajo kot osnovni način zatiranja filcavosti zatiranje kaparjev, kar je seveda zaradi poznavanja biologije glive smiselno (Choi et al., 2016). Navodila za zatiranje filcavosti citrusov v Indiji obsegajo higieno sadovnjaka, ustrezno dognojevanje in škropljenje z $1 \%$ bordojsko brozgo z dodatkom $25 \mathrm{ml}$ ribjega olja (NPCS, 2009). Lastnik sadovnjaka v Plavah v Soški dolini opaža, da se veje s številnimi trosnjaki $S$. marianii sušijo in da zaradi tega drevo lahko tudi odmre. Ustrezno bi bilo ugotoviti razširjenost in gostiteljske rastline glive pri nas, škodljivost filcavosti listavcev za sadno in gozdno drevje in morebitno potrebo za zatiralne ukrepe.

\section{ZAKLJUČKI}

V Sloveniji smo identificirali bolezen sadnega drevja, ki jo povzročata gliva Septobasidium marianii in rdeči hrušev kapar (Epidiaspis leperii). Bolezen je bila ugotovljena $\mathrm{v}$ dolini reke Soče $\mathrm{v}$ vasi Plave in njeni okolici predvsem na hruškah, pojavlja pa se tudi na našiju in jablanah. Bolezen smo poimenovali filcavost listavcev. Bolezen gostiteljskih dreves je posledica sesanja namnoženih kaparjev, ki jim gliva nudi ustrezne razmere za preživetje in namnožitev. Gliva je v mutualistični simbiozi s kaparji, je najočitnejše zunanje znamenje bolezni in jo po njenih trosnjakih najlažje ugotovimo. Veje in debla obolelih dreves lahko trosnjaki glive $S$. marianii množično prekrivajo in taka drevesa slabše priraščajo, hirajo, posamične veje tudi odmirajo in redko drevo celo odmre. Ukrepi za kontrolo bolezni obsegajo predvsem zatiranje kaparjev, poleg tega pa tudi odstranjevanje trosnjakov in uporabo fungicidov. Doslej v Sloveniji bolezen filcavost listavcev ni bila ugotovljena in to je prvo poročilo o pojavu te bolezni. Ustrezno bi bilo ugotoviti razširjenost in škodljivost filcavosti listavcev pri nas, njene gostitelje in proučiti smiselnost zatiralnih ukrepov.

\section{ZAHVALA}

Delo je bilo opravljeno v okviru del za Javno gozdarsko službo (Naloga 2A), ki jo financira Ministrstvo za kmetijstvo gozdarstvo in prehrano in v okviru Programske skupine Gozdna biologija, ekologija in tehnologija P4-0107, ki jo financira ARRS. O pojavu trosnjakov in 
postopnem hiranju drevja v sadovnjaku v Soški dolini nas je obvestil lastnik Srečko Križnič iz Plav pri Desklah, poslal je vzorce, slikovni material in nas ob terenskem ogledu vodil po obolelem sadovnjaku. Zahvaljujemo se mu za vso pomoč in zanimanje. Za recenzijo se zahvaljujemo recenzentom, glavnemu uredniku pa za številne popravke, ki so izboljšali tekst.

\section{VIRI}

Azema, R. (1975). Le genre Septobasidium Patouillard. Documents Mycologiques, 6, 1-24.

Choi, I. Y., Lee, W. H., Lee, J. J., Park, M. J., Ko, J. A., Choi, J. R., \& Shin, H. D. (2016) Characterization of a Septobasidium sp. associated with felt disease of Schisandra chinensis. Mycobiology, 4, 58-62. https://doi.org/10.5941/ MYCO.2016.44.1.58

Couch, J. N. (1931). The biological relationship between Septobasidium retiforme (B. \& C.) Pat. and Aspidiotus osborni New. and Ckll. Quarterly Journal of Microscopical Science, 74, 383-437. https://doi.org/10.1126/science.74.1922.437

Couch, J. N. (1938). The genus Septobasidium. University of North Carolina Press, Chapel Hill, North Carolina, USA.

Hauptman, T., \& Piškur, B. (2016). A new record of Rhizoctonia butinii associated with Picea glauca 'Conica' in Slovenia. Forest Pathology, 46, 259-263. https://doi.org/10.1111/ efp. 12272

Henk, D. (2008). Septobasidiales. Septobasidiaceae. Version 21, February 2008 (under construction). http://tolweb.org/ Septobasidiaceae/51247/2008.02.21 in The Tree of Life Web Project, Pridobljeno s http://tolweb.org/ (8. 4. 2019).

Henk, D.A., \& Vilgalys R. (2007). Molecular phylogeny suggests a single origin of insect symbiosis in the Pucciniomycetes with support for some relationships within the genus Septobasidium. American Journal of Botany, 94, 1515-1526. https://doi.org/10.3732/ajb.94.9.1515

Henk, D.A., \& Vilgalys, R. (2016). Genetic structure within Septobasidium colonies suggests outcrossing and frequent non self-fusion. Fungal Genomics \& Biology, 6, 143. https://doi. org/10.4172/2165-8056.1000143

Index Fungorum (2019): Pridobljeno s www.indexfungorum. org., http://www.indexfungorum.org/NAMES/NamesRecord.asp?RecordID=628764 (8. 4. 2019).

Jülich, W. (1984). Kleine Kryptogamenflora Band IIb/1. Die Nichtblätterpilze, Gallertpilze und Bauchpilze - Aphyllophorales, Heterobasidiomycetes, Gastromycetes. Gustav Fischer Stuttgart.

Martin, R., Gazis, R.O., Skaltsas, D., Chaverri, P., \& Hibbett, D. S. (2015). Unexpected diversity of basidiomycetous endophytes in sapwood and leaves of Hevea. Mycologia, 107, 284-297. https://doi.org/10.3852/14-206

Martini, E. (2016). Septobasidium marianii. Excerpts from Crusts and Jells. Descriptions and reports of resupinate Aphylloporales and Heterobasidiomycetes. No 71.

McRitchie, J.J. (1991). The felt fungus, Septobasidium. Plant Pathology Circular No. 346, Fla. Dept. Agric. \& Consumer Serv., Division of Plant Industry.

NPCS (Board of Consultants \& Engineers) (2009). Handbook on citrus fruits cultivation and oil extraction. Asia Pacific Business Press Inc., New Delhi.

Oberwinkler F. (2017). Yeasts in Pucciniomycotina. Mycological Progress, 16, 831-856. https://doi.org/10.1007/s11557017-1327-8

Porcelli, F. (2013). Distribuzione e significato della simbiosi fra Diaspididae (Rhynchota Coccoidea) e Septobasidium (Fungi). Atti Accademia Nazionale Italiana di Entomologia, LXI: 105-111.

Saccardo, P.A., \& Saccardo, D. (1905). Sylloge Fungorum Omnium Hucusque Cognitorum. Vol. 17: Supplementum Universale; Pars VI. Hymenomycetæ-Laboulbeniomycetæ, str. 204.

Seljak, G. (2010). A checklist of scale insects of Slovenia. Entomologia Hellenica, 19, 99-113. https://doi.org/10.12681/ eh.11577

Viennot-Bourgin, G. (1949). Les champignons parasites des plantes cultivées. Masson \& Cie, Vol 2.

White, T.J., Bruns, T., Lee, S., \& Taylor, J.W. (1990). Amplification and direct sequencing of fungal ribosomal RNA genes for phylogenetics. In: PCR protocols: a guide to methodsand applications. M.A. Innis, D.H. Gelfand, J.J. Sninsky, T.J. White (Eds.), AcademicPress, Inc., New York, NY, USA, pp. 315322. https://doi.org/10.1016/B978-0-12-372180-8.50042-1 